\title{
Controlled mass pollination in loblolly pine to increase genetic gains
}

\author{
by F. E. Bridgwater ${ }^{1}$, D. L. Bramlett ${ }^{2}$, T. D. Byram ${ }^{3}$ and W. J. Lowe ${ }^{3}$
}

Controlled mass pollination (CMP) is one way to increase genetic gains from traditional wind-pollinated seed orchards. Methodology is under development by several forestry companies in the southern USA. Costs of CMP depend on the efficient installation, pollination, and removal of inexpensive paper bags. Even in pilot-scale studies these costs seem reasonable. Net present values from CMP in a sample of sixty-seven loblolly pine (Pinus taeda L.) seed orchards in the Western Gulf Forest Tree Improvement Program are conservatively expected to average \$108 per acre of plantation established with seedlings from CMP among the best six parents in each of five breeding regions and $\$ 154$ per acre for CMP among the best pair of parents in each breeding region.

Key words: supplemental mass pollination, expected genetic gains, pollen contamination
La pollinisation globale contrôlée (PGC) constitue l'une des façons permettant d'accroître les gains génétiques par rapport à la pollinisation traditionnelle par le vent dans les vergers à graines. La méthodologie est actuellement en voie d'élaboration chez plusieurs compagnies forestières du sud des États-Unis. Les coûts de la PGC dépendent de l'installation efficiente, de la pollinisation et de l'enlèvement de sacs de papier peu dispendieux. Même dans les études préliminaires, ces coûts semblent raisonnables. Le coût net actuel de la PGC pour un échantillon de soixante-sept vergers à graines de pin du Sud (Pinus taeda L.) compris dans le programme d'amélioration génétique des arbres forestiers de l'ouest du Golfe devrait au bas mot totalisé une moyenne de $108 \$$ par acre de plantation établie à partir de semis produits par PGC effectuée entre les meilleurs six parents de chacune des cinq régions de reproduction et de $154 \$$ par acre pour une PGC réalisée entre la meilleur paire de parents de chacune des régions de reproduction.

Mots clés : pollinisation globale supplémentaire, gains génétiques attendus, contamination du pollen

\section{Introduction}

More than 10,000 acres of seed orchards have been grafted in the southern United States since the early 1960s. The bulk of these are loblolly pine (Pinus taeda L.) and slash pine (Pinus elliottii Engelm.). These orchards currently produce seeds for the more than a billion genetically improved seedlings planted each year (Bramlett 1991). The value of seeds from these orchards is increasing as more acres are rogued to increase the genetic quality and more advanced generation orchards are established. For example, the average gain in breeding value for volume for newly-grafted seed orchards rose from $20 \%$ in 1992 to $26.1 \%$ in 1996 in the Western Gulf Forest Tree Improvement Program (WGFTIP) (Byram and Lowe 1996). However, the potential genetic value of seeds from seed orchards is never reached because of pollen contamination. The full potential value of seed orchard seeds can only be achieved if all pollination is from parents within the seed orchard. Wind-borne pollen from outside the seed orchard is from genetically inferior parents, thus genetic gains are reduced. Pollen contamination was recognized as a potential problem from the initiation of southern pine tree improvement and seed orchards were established with isolation or pollen dilution zones surrounding them to reduce pollen contamination. These zones were typically 400 feet wide and were planted with species that flowered out of synchrony with the seed orchard parents or were left unplanted. These barriers did not prevent pollination as trees in seed orchards in which

${ }^{1}$ USDA-Forest Service, Forest Science Lab, Texas A\& M University, College Station, TX 77843-2585.

${ }^{2}$ USDA-Forest Service (Retired), Southern Research Station, Juliette, GA 31046. ${ }^{3}$ Western Gulf Forest Tree Improvement Program, Texas Forest Service, Forest Science Lab, Texas A \& M University, College Station, TX 77843-2585. all trees had been emasculated produced sound seeds in slash pine (Squillace 1967) and in Scots pine (Pinus sylvestris L.) (Hadders 1973). These barriers may have reduced pollen contamination, but estimates show that it is still substantial. Pollen contamination in reproductively mature loblolly pine seed orchards has been estimated to be $28 \%$ to $48 \%$ (Friedman and Adams 1981) and contamination often exceeds $60 \%$ in young (less than 10 years old) loblolly orchards (Lowe and Wheeler 1993). Contamination as high as $83.5 \%$ was estimated for a 16-year-old slash pine seed orchard (Squillace and Long 1981). Genetic gains are theoretically reduced by half in the proportion of the seeds produced by contaminating pollen. Thus, there is great incentive to reduce or eliminate pollen contamination. Furthermore, as the expected genetic gains from seed orchards increase from roguing or from establishing orchards with advanced generation selections, the absolute losses will be greater.

Ideally, pollen parentage would be completely controlled. This would eliminate pollen contamination and would permit positive assortative mating among seed orchard parents to maximize genetic gains. Although seed orchard clones are highly selected, substantial genetic differences exist among parents within seed orchards. Controlled pollinations (CP) are routinely done with southern pines to produce pedigreed crosses for breeding (Bramlett and O'Gwynn 1981). However, the expense of traditional $\mathrm{CP}$ has precluded its use to produce large numbers of seeds. $\mathrm{CP}$ was used successfully to produce Pinus rigida $\times$ P. taeda hybrids on a large scale (Hyun 1976). However, rising labor costs made the procedure impractical.

Less expensive methods for producing large numbers of controlled pollinated seeds have been attempted. Supplemental mass pollination (SMP) is the application of desired pollen par- 
ents to female reproductive structures without physically isolating them from ambient pollen. Successful mass pollination experiments have been reported for several species (See Bridgwater and Trew 1981, and Bridgwater et al. 1993 for summaries). Unfortunately, SMP applied on an operational scale in southern pine seed orchards has not been successful (Bramlett 1991). This may be because processed pollen is less able to compete with wind-borne pollen (Davis et al. 1997) or because extremely variable development among strobili within ramets (Askew 1988) makes it difficult to pollinate every strobilus at peak receptivity. The failure to successfully implement SMP on an operational scale in southern pine seed orchards resulted in the development of more efficient and less expensive methods of $\mathrm{CP}$. CP practiced on a large scale using less expensive methods is referred to as controlled mass pollination (CMP).

We will describe the process as it has developed to date, examine the opportunity to increase genetic gains from CMP in a sample of loblolly pine seed orchards, and discuss biological and operational factors that impact costs of producing CMP seeds.

\section{CMP Methods}

Contamination by unwanted pollen must be prevented in $\mathrm{CP}$ to produce pedigreed seeds for breeding. This is accomplished by isolating female strobili, that are tightly enclosed by the bud scales, using isolation bags that exclude pollen and a pollen-excluding material at the connection of the isolation bag with the stem. An internal support is fastened to the limb to prevent bag damage to the strobili (Bramlett and O'Gwynn 1981). This method is labor intensive and a skilled operator can rarely install more than 80 to $100 \mathrm{CP}$ bags in an eight-hour day. CMP has been made more efficient by using inexpensive paper bags that can be installed quickly. No pollen-excluding material is used at the base of the bag and no internal support is required. The bag is made self-supporting by creasing the end into a box-like shape. Paper bags can be installed three to five times faster than sausage casing bags, and a skilled two-man crew can install hundreds in an eighthour day. There is also a significant cost savings in materials used for bagging. $\mathrm{CP}$ materials cost $\$ 1$ to $\$ 2$ per bag while paper bags and fasteners for attaching them to branches are commercially available for about $\$ 0.04$ per bag. Pollination is also more efficient with CMP if the risk of some contamination is acceptable since entry holes made in bags for pollination need not be resealed as they must be in CP.

The paper bag we have evaluated is a Kraft bag manufactured by the Lawson Company ${ }^{4}$ for commercial pollinations in agricultural crops. The bag has "shower-proof" glue and can withstand the strong winds common in the southeastern U.S. during the breeding season. Complete details of the CMP process are given elsewhere (Bramlett 1997) but briefly, it requires: 1) a mating strategy, for example making specific matings or polymix crosses, 2) detailed knowledge of male and female flowering phenology of the CMP parents, 3 ) capability to collect, process, (and store if fresh pollen is not used) large quantities of pollen, and 4) developing a strategy for pollinations.

\footnotetext{
${ }^{4}$ The use of trade or firm names in the publication is for reader information and does not imply endorsement by the U.S. Department of Agriculture of any product or service (FSM1609.11).
}

This last requirement incorporates all of the details of executing the CMP strategy. For example, how many times and at what stage(s) of development should pollinations be made? Will strobili which are not bagged be marked, removed or simpiy harvested with CMP cones and accepted as contaminants.

\section{Potential for CMP}

The marginal increase in genetic gains from CMP depends on the breeding values of the CMP parents and the alternative seed source. Most orchardists using CMP in the southern USA make specific crosses among parents with the best general combining abilities in existing seed orchards that are reproductively mature. This is the simplest approach, but many alternatives exist and may be very specific to each organization, its objectives, and capabilities. Some alternatives are listed below in approximately increasing order of complexity and cost.

1. Use CMP in an existing seed orchard using fresh pollen. This strategy requires that males flower before females sufficiently early to permit pollen collection and processing. Males and females need not be in the same location if fresh pollen can be transported. Having males in a seed orchard located in a climate which promotes early flowering would have an added advantage of increasing the time between pollen collection and female receptivity.

2. Use CMP in an existing seed orchard using stored pollen. This strategy requires the capability and expertise necessary to properly process and store large quantities of pollen. Seed yields will be reduced if pollen is not properly processed and stored (Bramlett and Matthews 1991).

3. Construct a CMP seed orchard. This strategy will reduce the costs of operation since only CMP parents will be in the seed orchard. Thus, the total area that must be managed is less than in an existing seed orchard. This strategy should greatly reduce the cost of operations if highly reproductive parents are used. However, there are significant disadvantages to establishing a new CMP orchard. After establishing a new orchard there is a delay of several years before grafts begin producing strobili in sufficient numbers to make CMP efficient. Large trees with many female strobili are the most efficient for CMP. However, it may be possible to replace crowns using topworking to change genotypes in existing seed orchards and significantly reduce the time delay from grafting to seed production (Bramlett 1997). Future management options are also limited as CMP orchards are likely to be established with too few clones and poor field designs for use as open-pollinated orchards.

4. Make $\mathrm{CP}$ crosses among the best specific combiners. The first three strategies are based on capturing gains from mating the best general combiners. All three assume that there is no specific combining ability or that it is not known. If parents that exhibit positive specific combining ability can be identified, expected gains will be greater. However, this requires that these specific combinations have been tested in field trials. Most large breeding programs in the southern USA plan to use complementary mating designs (Lowe and van Buijtenen 1986) which rely on polymix tests to estimate the general combining abilities of parents. Since breeding values are known 
Table 1. Expected percentage gains in volume mean annual increment at age 20 from seed orchards in five breeding regions with different pollination strategies.

\begin{tabular}{|c|c|c|c|c|c|}
\hline Breeding region $^{1}$ & $\mathrm{AR} / \mathrm{OK}$ & N. LA & S. LA & MS & E. TX \\
\hline Number of seed orchards & 21 & 17 & 7 & 6 & 16 \\
\hline Worst seed orchard & 7.7 & 19.7 & 12.2 & 15.1 & 14.2 \\
\hline Mean seed orchard & 15.6 & 22.2 & 12.9 & 15.3 & 17.6 \\
\hline Best seed orchard & 16.9 & 25.6 & 17.1 & 15.5 & 19.1 \\
\hline $30 \%$ contamination $^{2}$ & 13.3 & 18.9 & 11.0 & 13.0 & 15.0 \\
\hline $\mathrm{CMP}^{3}$ & 26.7 & 35.4 & 24.9 & 30.1 & 34.4 \\
\hline CMP5 & 27.3 & 36.3 & 25.8 & 30.6 & 35.3 \\
\hline CMP4 & 28.1 & 37.5 & 26.7 & 31.2 & 36.5 \\
\hline CMP3 & 29.2 & 38.9 & 27.7 & 32.2 & 38.2 \\
\hline CMP2 & 30.9 & 41.3 & 29.0 & 33.8 & 40.8 \\
\hline
\end{tabular}

${ }^{1}$ Breeding regions within the Western Gulf Forest Tree Improvement Program in the southern USA.

${ }^{2}$ Average seed orchard in each region assuming $30 \%$ contaminating pollen from outside the orchard.

${ }^{3}$ Controlled mass pollination among the best 2 to 6 parents assuming all possible crosses are made averaged for the region.

before controlled matings occur the full-sib progenies need not be planted in replicated trials, but may be planted in block plots for individual-tree selection. Use of this fourth CMP strategy necessitates field testing full-sib progenies to determine the best specific combinations.

The gains from any strategy must be compared to alternatives in order to determine if that strategy is to be profitable. For example, the marginal gains from CMP might be estimated as the difference between the average breeding values of the two best parents in a seed orchard and the mean of all breeding values in that seed orchard. If there is a surplus of seeds it may not be desirable to harvest the entire crop. In this case the appropriate basis of comparison would be the expected genetic gain from the few best parents in the seed orchard when mated with all of the parents in the seed orchard.

Estimated gains in volume mean annual increment at age 20 from 67 seed orchards currently producing seeds for cooperators in the WGFTIP are given in Table 1. These seed orchards include first-generation seed orchards with varying degrees of roguing as well as advanced-generation seed orchards that incorporate the best first-generation progeny-tested parents and their selected progenies. The WGFTIP does not have distinct generational seed orchards, but uses an advancing-front concept where small blocks of seed orchard are established at regular time intervals with the best genetic material available without regard to generation (Lowe and van Buijtenen 1986). The marginal increases in genetic gain from CMP are estimated for each breeding region because parents adapted to one region are not generally well-adapted to another. Expected genetic gains for the worst, average and best seed orchard within each region are presented, but the comparison we wish to draw is between the means of the average seed orchards, assuming $30 \%$ pollen contamination and CMP among the best two to six parents for each region. Using the worst seed orchard as a basis of comparison is not realistic because these seed orchards will soon be abandoned as seed orchards of higher value begin to produce more seeds. Using the best seed orchard as a comparison assumes that each cooperator in a region would establish a new seed orchard with material exactly like the best seed orchard. This is not practical. Furthermore, the best seed orchard changes over time as new orchard blocks are established at different times by different cooperators. The assumption of $30 \%$ pollen contamination yields a conservative estimate of the marginal gains from CMP since much higher estimates have been made (Friedman and
Adams 1981, Lowe and Wheeler 1993, and Squillace and Long 1981).

The marginal increase in genetic gains for volume growth rate (mean annual increment at age 20) from CMP between the two best parents for Arkansas/Oklahoma, North Louisiana, South Louisiana, Mississippi and East Texas are 17.6\%, $22.4 \%, 18.0 \%, 20.8$, and $25.8 \%$, respectively, and $13.4 \%, 16.5 \%$, $13.9 \%, 17.1 \%$ and $19.4 \%$ for CMP among the best 6 parents. It is apparent that substantial gains can be made from CMP in all of the breeding regions, but the question of profitability remains.

\section{Present Value of CMP Seeds}

Costs of producing seeds from CMP are not available since most of the operational programs are being developed by private companies. Costs of CMP will primarily be for labor to install bags, complete pollinations and remove bags. Aerial lift equipment will be required for 4 to 5 weeks. Factors such as the numbers of female strobili per bag and the numbers of seeds per cone will also have a significant impact on the cost of producing CMP seeds. It is possible to estimate the present value of CMP seeds and provide some benchmark for break-even costs. Estimating present value for CMP seeds from available information requires several assumptions. The first, and possibly most important, assumption is how predicted genetic gains will be realized. For example, the expected genetic gains for seed orchards in the WGFTIP are in units of mean annual increment in stand volume at age 20 (MAI20). Harvest ages, site indexes, management strategy and other factors differ among organizations and these will change the realization of genetic gains. Our worked example assumes an average site index of 50 at age 25,680 trees per acre planted, $85 \%$ survival at age 1 , no thinning, and a final harvest at age 25 . We used the North Carolina State University Managed Loblolly Pine Plantation Growth and Yield Simulator (Hafley and Buford 1985) incorporating a height/age relationship for old-field loblolly pine plantations (Golden et al. 1981) to relate expected genetic gains in MAI20 to stand stumpage values (Table 2). Stumpage values were estimated by multiplying cords of pulpwood and thousands of board feet of lumber by \$21 and \$421, respectively (Texas Forest Service 1996). Percentage gain was regressed on stumpage value producing the equation:

Stumpage value at age $25=\$ 1208.80+(\$ 28.04) \times(\%$ gain in MAI20). 
Table 2. Estimated values from the North Carolina State University Managed Loblolly Pine Plantation Growth and Yield Simulator and Stumpage Values age 25 By Site Index

\begin{tabular}{|c|c|c|c|c|c|c|}
\hline Site index & MAI at 20 & $\begin{array}{c}\text { At age } 20 \\
\% \text { Gain }\end{array}$ & Mbf & Pulp(cu ft) & $\begin{array}{r}\text { At age 25 } \\
\text { Pulp (cds) } \\
\end{array}$ & Stumpage(\$) \\
\hline 50 & 72.5 & 0.00 & 2.0 & 1279 & 16.8 & 1195.46 \\
\hline 51 & 76.4 & 5.38 & 2.4 & 1294 & 17.0 & 1367.90 \\
\hline 52 & 80.5 & 11.03 & 2.7 & 1306 & 17.2 & 1497.65 \\
\hline 53 & 84.6 & 16.69 & 3.1 & 1317 & 17.3 & 1669.09 \\
\hline 54 & 88.7 & 22.34 & 3.5 & 1322 & 17.4 & 1838.76 \\
\hline 55 & 92.9 & 28.14 & 3.9 & 1326 & 17.5 & 2008.41 \\
\hline 56 & 97.1 & 33.93 & 4.3 & 1332 & 17.5 & 2178.33 \\
\hline 57 & 101.4 & 39.86 & 4.7 & 1339 & 17.6 & 2348.80 \\
\hline 58 & 105.7 & 45.79 & 5.0 & 1347 & 17.7 & 2477.14 \\
\hline 59 & 110.0 & 51.72 & 5.4 & 1352 & 17.8 & 2647.03 \\
\hline 60 & 114.4 & 57.79 & 5.8 & 1355 & 17.8 & 2816.15 \\
\hline
\end{tabular}

Site index is height at base age 25 years, MAI at 20 is mean annual increment at age $20, \%$ gain was calculated using MAI at 20 , site index 50 as a base, Mbf is thousand board feet, cords of pulpwood were estimated by dividing Pulp $(\mathrm{cu} \mathrm{ft})$ by $76 \mathrm{cu} \mathrm{ft} \cdot \mathrm{cord}^{-1}$, stumpage was calculated by multiplying Mbf $\times \$ 421$ and Pulp (cds) · \$21 and summing. Stumpage prices are averages from Texas Timber Price Trends (Texas Forest Service 1996) for 1994, 1995 and 1996.

Both the intercept and the slope were significantly different from zero at $\mathrm{Prob}>|\mathrm{T}|=0.0001$ and an $R^{2}=0.9992$. Thus, increasing genetic gain in MAI20 by $1 \%$ is expected to increase the stumpage value of a stand under our conditions by $\$ 28 /$ acre at age 25 . Since these gains will not be realized until harvest, we discounted stumpage value for 28 years ( 2 years to produce seeds, 1 year to grow and plant a seedling, and 25 years until harvest). The stumpage value discounted for 28 years at $4 \%$ compound interest is $\$ 9.35$. This value is spread among 680 seedlings on each acre, therefore, the additional value of each seedling with an expected genetic gain in MAI20 of $1 \%$ is $\$ 0.01375$. This present value must be further reduced because the percentage of seedlings planted per seed sown is about $80 \%$. Thus, the additional value of each seed is $\$ 0.011$ per percentage gain in MAI20. Most orchardists are confident that they can achieve average costs per seed of about $\$ 0.05$. This implies that only $5 \%$ genetic gain in MAI20 is required to break even. The difference between the average of all seed orchards in each region with $30 \%$ contamination and the average expectation for CMP among the best 6 parents is $16.1 \%$ (Table 1). If costs per seed are $\$ 0.05$ and $16.1 \%$ additional gain is possible, then the present value of the genetic gain from CMP is $\$ 0.177$. Deducting the cost per seed $(\$ 0.05)$ leaves $\$ 0.127$ per seed net present value. Since 850 seeds are required to plant an acre, the average expected net return per acre is $\$ 108$. If CMP were done only between the best pairs of parents, the increase in expected genetic gain from CMP is $21 \%$, and the net present value of CMP is $\$ 154$ per acre. These estimates assumed no pollen contamination with CMP. In practice, this means that female strobili not bagged must be removed, or marked and kept separate at harvest. Otherwise, expected gains from CMP must be reduced proportionately for ambient pollen which would be approximately $70 \%$ from seed orchard parents and $30 \%$ contamination from outside the seed orchard. Experience to date suggests that seeds from non-CMP seeds range from $5 \%$ to $40 \%$ of the total filled seeds when strobili that are not bagged are harvested with the CMP crop.

\section{Summary}

Controlled mass pollination is one way to increase the genetic gains from traditional wind-pollinated seed orchards. Costs, even in pilot-scale studies, seem reasonable. Net present values from CMP in a sample of sixty-seven seed orchards in the Western Gulf Forest Tree Improvement Program are conservatively expected to average $\$ 108$ per acre for CMP among the best six parents in each of five breeding regions and \$154 per acre for CMP among the best pair of parents in each breeding region.

\section{Acknowledgments}

We wish to thank the cooperating members of the Western Gulf Forest Tree Improvement Program for the use of their data in this analysis.

\section{References}

Askew, G. R. 1988. Estimation of gamete pool compositions in clonal seed orchards. Silvae Genetica 37(5-6): 227-232.

Bramlett, D.L. 1991. Seed orchard management - successes, problems and challenges. pp. 82-92. In Proc. 21st Southern Forest Tree Improvement Conference, June 17-20, Knoxville, TN. 342 pp.

Bramlett, D.L. 1997. Genetic gain from mass controlled pollination and topworking. Journal Forestry. 95(3): 15-19.

Bramlett, D. L. and F. R. Matthews. 1991. Storing loblolly pine pollen. South. J. Appl. For. 15(3): 153-157.

Bramlett, D.L. and C. H. O'Gwynn. 1981. Controlled Pollination. pp. 44-51. In: Pollen Management Handbook. E. C. Franklin (ed.). USDA Forest Service, Agric. Handbook 587, Washington, D.C. 98 pp.

Bridgwater, F. E. and I. F. Trew. 1981. Supplemental Mass Pollination. pp. 52-57. In: Pollen Management Handbook. E. C. Franklin (ed.) USDA Forest Service, Agric. Handbook 587, Washington, D.C. $98 \mathrm{pp}$.

Bridgwater, F. E., T. D. Blush, and N. C. Wheeler. 1993. Supplemental Mass Pollination, pp 69-77. In Advances in Pollen Management, eds. D. L. Bramlett, G.R. Askew, T. D. Blush, F. E. Bridgwater, and J. B. Jett, USDA Forest Service, Agriculture Handbook 698, Washington, D.C. 101 p.

Byram, T. D. and W. J. Lowe. 1996. Forty-fourth progress report of the cooperative forest tree improvement program. Texas Forest Service, College Station, TX. Circular 296. 25 pp.

Davis, K. B., T. L. Kubisiak, F. E. Bridgwater, and D. L. Bramlett. 1997. Use of RAPD markers to investigate the effects of pollen processing and pollen storage on pollen vigor. In: Proc. 24th Southern Forest Tree Improvement Conference, June 90-12, 1997, Orlando, FL.

Friedman, S.T. and W.T. Adams 1981. Genetic efficiency in loblolly pine seed orchards. pp. 213-220. In: Proc. 16th Southern Forest Tree Improvement Conference, May 27-28, 1981, Blacksburg, VA. $363 \mathrm{pp}$.

Golden, M. S., R. Meldahl, S. A. Knowe and W. D. Boyer. 1981. 
Predicting site index for old-field loblolly pine plantations. South. J. Appl. For. 5(3): 109-114.

Hadders, G. 1973. Monitoring inbreeding in a Scots pine seed orchard. Foren. Skogstradsforadling och Inst. Skogsforbattring, arsbok 1972. pp. 129-139. (Forestry Abstracts. 34: 6941).

Hafley, W. L. and M. A. Buford. 1985. A bivariate model for growth and yield prediction. For. Sci. 31: 237-247.

Hyun, S. K. 1976. Interspecific hybridization in pines with the special reference to Pinus rigida $\times$ Pinus taeda. Silvae Genetica 25: 188-191.

Lowe, W.J. and J.P. van Buijtenen 1986. The development of a sublining system in an operational tree improvement program. pp. 98-106. In: Proc. IUFRO Conf. On Breeding Theory, Progeny Testing, and Seed Orchards. October 13-17, 1986, Williamsburg, VA. $673 \mathrm{pp}$.
Lowe, W. J. and N. C. Wheeler 1993. Pollen Contamination in Seed Orchards. pp 49-53. In Advances in Pollen Management. D. L. Bramlett, G.R. Askew, T. D. Blush, F. E. Bridgwater, and J. B. Jett (eds.). USDA Forest Service, Agriculture Handbook 698, Washington, D.C. 101 pp.

Squillace, A. E. 1967. Effectiveness of 400 -foot isolation around a slash pine seed orchard. Journal of Forestry. 65(11): 823-824.

Squillace, A. E. and E. M. Long. 1981. Proportion of Pollen from Non Orchard Sources. pp. 15-19. In: Pollen Management Handbook. E. C. Franklin (ed.). USDA Forest Service, Agric. Handbook 587, Washington, D.C. 98 pp.

Texas Forest Service. 1996. Texas Timber Price Trends. Vol. 14(6), Texas Forest Service, College Station, TX. 14 pp. 